\title{
PREDIKSI TINGGI CURAH HUJAN DAN KECEPATAN ANGIN BERDASARKAN DATA CUACA DENGAN PENERAPAN ALGORITMA ARTIFICIAL NEURAL NETWORK (ANN)
}

\section{RAINFALL AND PREDICTION WIND SPEED ACCORDING TO WEATHER DATA HISTORY WITH ARTIFICIAL NEURAL NETWORK APPLICATION (ANN)}

\author{
Nenni Mona Aruan, S.Pd, M.Si ${ }^{1}$, Firman Maranatha Sihombing ${ }^{1 *}$, Doni Albert Hasiholan Panggabean ${ }^{1}$ \\ ${ }^{1}$ Institut Teknologi Del, Jl.P.I.Del,Sitoluama, Laguboti, Kabupaten Toba, Sumatera Utara \\ *E-mail: mfirmanmaranatha@gmail.com
}

\begin{abstract}
ABSTRAK
Kondisi cuaca merupakan faktor yang sangat mempengaruhi aktivitas manusia khususnya pada sektor transportasi karena kegiatan lalu lintas udara dan laut dilakukan dengan mempertimbangkan kondisi cuaca seperti hujan dan kecepatan angin. Untuk itu-prediksi curah hujan dan angin penting dilakukan, sehingga semua kegiatan lalu lintas direncanakan dengan baik. Untuk mendapatkan hasil prediksi yang akurat, perlu dilakukan penelitian algoritma apa yang terbaik dan efektif. Pada penelitian ini dilakukan perbandingan pemodelan dari algoritma neural network yaitu Backpropagation (BPNN) dan Reccurent neural network (RNN). Dataset yang digunakan dalam penelitian ini adalah data cuaca periode 2010-2019 dari stasiun FL Tobing Badan Meteorologi, Klimatologi dan Geofisika yang berada di Kabupaten Tapanuli Tengah. Implementasi jaringan syaraf tiruan Backpropragation dan Reccuren dilakukan dengan membangun pemodelan prediksi, dimana dataset yang digunakan akan dinormalisasi terlebih dahulu untuk mendapatkan nilai RMSE terkecil. Berdasarkan percobaan yang telah dilakukan didapatkan bahwa dalam pemodelan prediksi curah hujan dengan nilai RMSE terkecil sebesar 0,079535 menggunakan algoritma $B P N N$. Sedangkan untuk pemodelan prediksi kecepatan angin diperoleh nilai RMSE terkecil sebesar 0,06281251 menggunakan algoritma RNN. Melalui penelitian ini didapatkan bahwa algoritma BPNN lebih baik dalam memprediksi curah hujan dan algoritma RNN lebih baik dalam memprediksi kecepatan angin.
\end{abstract}

Kata kunci: RMSE, Curah Hujan, Kecepatan Angin, BPNN, RNN.

\begin{abstract}
Weather conditions are a factor that greatly affects human activities, especially in the transportation sector because air and sea traffic activities are carried out by considering weather conditions such as rain and wind speed. For this reason, it is important to predict rainfall and wind, so that all traffic activities are well planned. To get accurate prediction results, it is necessary to research what algorithm is the best and most effective. In this study, a comparison of the modeling of the neural network algorithms, namely Backpropagation (BPNN) and Reccurent neural network (RNN) was carried out. The dataset used in this study is weather data for the 2010-2019 period from the FL Tobing Station of the Meteorology, Climatology and Geophysics Agency located in Central Tapanuli Regency. The implementation of Backpropragation and Reccuren neural networks is done by building prediction modeling, where the dataset used will be normalized first to get the smallest RMSE value. Based on the experiments that have been carried out, it was found that in modeling the rainfall prediction with the smallest RMSE value of 0.079535 using the BPNN algorithm. Meanwhile, for wind speed prediction modeling, the smallest RMSE value is 0.06281251 using the RNN algorithm. Through this study, it was found that the BPNN algorithm is better at predicting rainfall and the RNN algorithm is better at predicting wind speed.
\end{abstract}

Keywords: RMSE, Rainfall, Wind Speed, BPNN, RNN. 


\section{PENDAHULUAN}

Cuaca adalah keadaan udara pada saat tertentu dan pada wilayah tertentu yang relatif sempit dan pada jangka waktu yang singkat [1]. Terdapat beberapa faktor yang dapat mempengaruhi cuaca seperti curah hujan dan kecepatan angin. Curah hujan adalah jumlah air yang jatuh di permukaan tanah datar selama periode tertentu yang diukur dengan satuan tinggi $(\mathrm{mm})$ di atas permukaan horizontal [2].

Negara Kesatuan Republik Indonesia memiliki wilayah negara yang dilintasi oleh garis ekuator sehingga dapat dikategorikan sebagai negara tropis. Oleh karena itu, curah hujan di Indonesia termasuk cukup tinggi. BMKG (Badan Meteorologi Klimatologi dan Geofisika) mencatat Indonesia memiliki rata rata curah hujan yang cukup tinggi yaitu 2000 sampai 3000 milimeter per tahunnya [2].

Penelitian ini mengacu pada penelitianpenelitian sebelumnya, dimana beberapa penelitian sebelumnya juga melakukan pemodelan curah hujan baik menggunakan pendekatan matematis maupun menggunakan pendekatan machine learning dengan jumlah variabel yang berbeda-beda.

$$
\text { Penelitian ini menggunakan }
$$

pendekatan machine learning yang sudah tergolong kedalam neural networks, karena dengan pendekatan neural networks akan lebih membantu dibanding dengan pendekatan secara matematis. Hal ini dikarenakan dengan pendekatan neural networks, proses melakukan prediksi curah hujan dan kecepatan angin lebih cepat dan juga lebih akurat [3]. Pada penelitian sebelumnya, dapat dibuktikan bahwa hasil prediksi yang didapat akan lebih akurat jika ditambahakan variabel-variabel pendukung yang dapat menambah keakuratan hasil prediksi [4]. Dengan begitu, penelitian ini bermaksud untuk melakukan prediksi terhadap tinggi curah hujan dan juga prediksi kecepatan angin berdasarkan data cuaca menggunakan pendekatan machine learning dan melakukan penambahan variabe-variabel pendukung yang dapat menambah keakuratan dari hasil prediksi.

Pada penelitian ini dilakukan perbandingan hasil prediksi antara algoritma Recurrent Neural Network (RNN) dan Backpropagation Neural Network (BPNN). Pemilihan algoritma BPNN dilakukan dengan mengacu pada penelitian terdahulu yaitu "Prediksi Curah Hujan di Deli Serdang dengan Backpropagation Neural Network, Deep Belief Network, dan Support Vector Regression" yang dimana pada penelitian sebelumnya didapatkan bahwa algoritma Backpropagation Neural Network (BPNN) merupakan algoritma terbaik dalam melakukan prediksi curah hujan [5]. Algoritma Pada penelitian ini akan dilakukan perbandingan hasil prediksi antara algoritma Recurrent Neural Network (RNN) dan Backpropagation Neural Network (BPNN). Kedua pemodelan tersebut akan dibandingkan dengan mencari nilai error terkecil, kemudian model yang memiliki nilai error terkecil ditetapkan sebagai model terbaik dalam prediksi tinggi curah hujan. Berdasarkan beberapa penelitian sebelumnya, dinyatakan bahwa algoritma Backpropagation Neural Network (BPNN) merupakan algoritma terbaik dalam melakukan prediksi curah hujan.

Penelitian ini akan melakukan prediksi terhadap tinggi curah hujan dengan 9 variabel di antaranya curah hujan, lama penyinaran matahari, suhu maksimum, suhu minimum, suhu rata-rata, tekanan udara, kelembaban udara, arah angin, dan kecepatan angin. Dan juga melakukan prediksi terhadap kecepatan angin dengan 9 variabel di antaranya curah hujan, lama penyinaran matahari, suhu maksimum, suhu minimum, suhu rata-rata, tekanan udara, kelembaban udara, arah angin, dan kecepatan angin.

Recurrent Neural Network (RNN) dengan arsitektur LSTM dan Backpropagation Neural Network (BPNN) adalah tipe dari sebuah neural networks dimana hasil keluaran ataupun output dari dari beberapa operasi sebelumnya akan menjadi nilai masukan ataupun input dari operasi yang akan dijalankan berikutnya. Dalam neural networks sederhana, semua input dan output berdiri terpisah dan tidak terkait satu sama lain, tetapi pada beberapa kasus seperti ketika memperkirakan keadaan berikutnya, semisal seperti memprediksi kata berikutnya dalam sebuah kalimat, kata sebelumya akan dibutuhkan.

RNN memiliki keterbatasan dalam membaca atau menyimpan informasi dari sebuah proses dalam jangka panjang. Hal ini membuat keterbatasan untuk menjaga konsistensi informasi yang harus dikaitkan dalam setiap pemanggilan fungsi rekursif berikutnya. Untuk mengatasi persoalan tersebut, RNN mengalami adaptasi terhadap bentuk dan arsitekturnya agar dapat menyimpan informasi hasil perhitungan sebelumnya yang disebut dengan LSTM (Long-Short Term Memory) dimana terdapat adaptasi sebuah cell baru yang disebut dengan memory cell yang 
bertujuan untuk menjaga konsistensi informasi setiap perhitungan rekursif. Untuk Menyusun pemodelan dengan menggunakan dataset yang memiliki rentang waktu cukup panjang, maka algoritma RNN dengan arsitektur LSTM (LongShort Term Memory) dinilai lebih efektif dan dapat dijadikan sebagai pembanding untuk algoritma BPNN seperti yang telah dijelaskan sebelumnya.

\section{METODOLOGI}

Pada penelitian ini, dilakukan pemodelan prediksi untuk melihat dan mengamati tinggi curah hujan dan kecepatan angin berdasarkan data cuaca di wilayah Tapanuli Tengah dan sekitarnya. Berikut desain dari pemodelan yang akan dibangun:

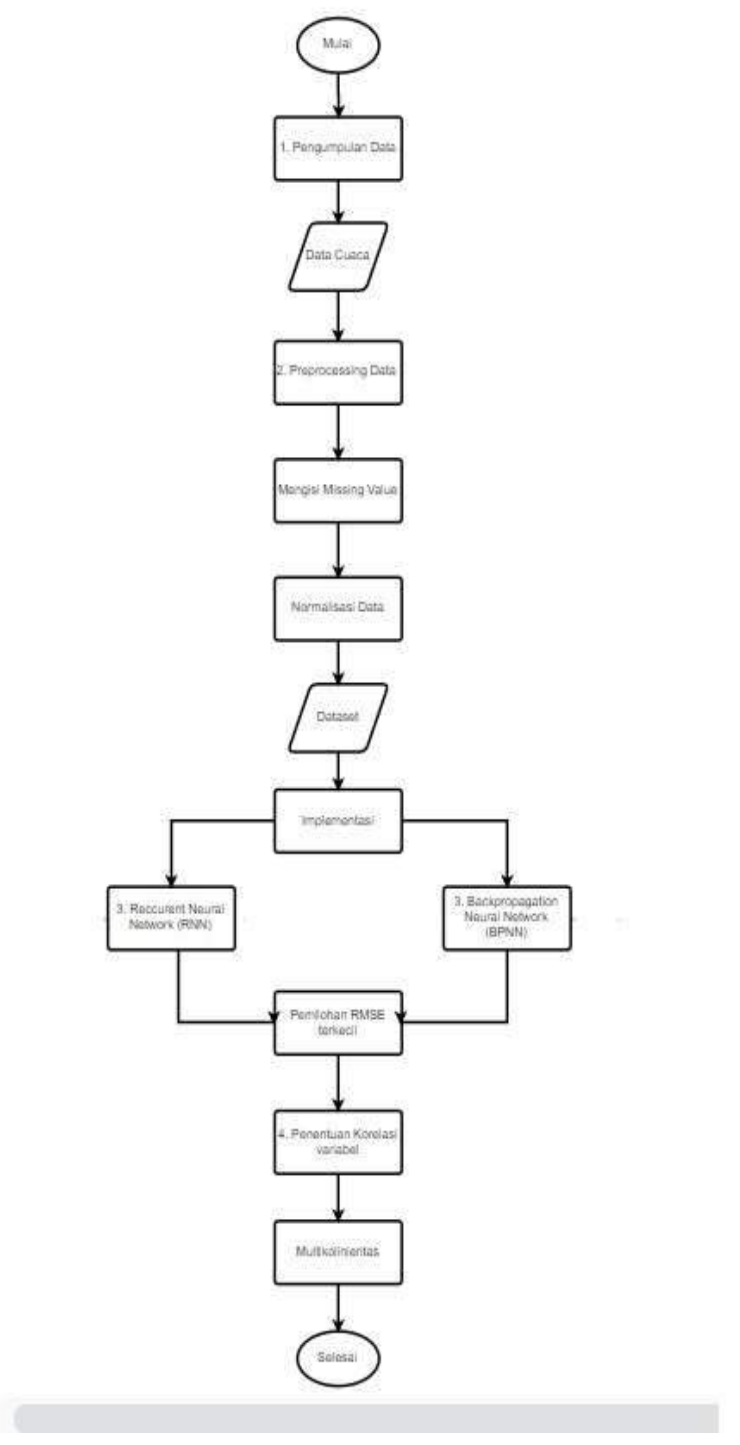

Gambar 1. Flowchart Metodologi Penelitian

\section{Pengumpulan Data}

Pada penelitian ini, data cuaca yang digunakan merupakan data cuaca yang diambil dari Badan Meteorologi Klimatologi dan
Geofisika (BMKG) dengan jangka waktu 10 tahun yaitu dimulai dari Januari 2010 hingga Desember 2019. Pada tahap seleksi data dilakukan dengan melakukan pemilihan faktor yang dapat mempengaruhi keakuratan dari hasil prediksi tinggi curah hujan dan kecepatan angin. Berdasarkan seleksi data tersebut, penelitian ini menggunakan data sesuai faktor yang mempengaruhi curah hujan dan kecepatan angin. Adapun data yang digunakan dalam melakukan prediksi terhadap curah hujan yaitu curah hujan, lama penyinaran matahari, suhu maksimum, suhu minimum, suhu rata-rata, kelembaban udara, dan kecepatan angin. Data yang digunakan dalam melakukan prediksi terhadap kecepatan angin yaitu curah hujan, suhu maksimum, suhu minimum, suhu ratarata, kelembaban udara, arah angin, dan kecepatan angin.

\section{Data Preprocessing}

Preprocessing merupakan tahapan dalam melakukan pemrosesan terhadap data sebelum data tersebut siap digunakan dalam melakukan pemodelan. Preprocessing dibutuhkan agar data dapat digunakan dalam pemodelan, dikarenakan data yang didapat dari BMKG memiliki beberapa nilai yang hilang atau kosong, sehingga perlu dilakukan preprocessing data agar data tersebut sudah siap dan layak digunakan dalam melakukan pemodelan.

\subsection{Mengisi Missing Value}

Setelah memperoleh data yang akan digunakan dalam membangun pemodelan prediksi, tahapan pertama yang harus dilakukan adalah melakukan preprocessing dataset, dimana dilakukan pengisian data yang kosong dengan nilai rata-rata dari data sebelum dan sesudah dari data yang kosong.

\subsection{Normalisasi Data}

Setelah data yang kosong diisi dengan mengguakan arsitektur rata-rata atau mean, maka dilakukan normalisasi dengan tujuan untuk mendapatkan data dengan ukuran yang lebih kecil dan mewakili data yang asli tanpa kehilangan karakterisitiknya sendiri [6].

\section{Implementasi}

Setelah dilakukan pre processing yaitu dengan mengisi Missing value dan melakukan normalisasi data, maka setelah itu dilakukan pemodelan prediksi dengan menggunakan algoritma Backpropagation Neural Network dan Reccurent Neural Network dengan 
arsitektur long short term memory. Pada tahap implementasi akan dilakukan beberapa percobaan pemodelan untuk mendapatkan pemodelan terbaik dalam melakukan prediksi curah hujan dan kecepatan angin dengan memperhatikan nilai RMSE yang didapatkan.

Tabel 1. Spesifikasi Percobaan Prediksi Curah Hujan dan Kecepatan Angin

\begin{tabular}{ll}
\hline Validation Split & $0.1,0.2,0.3,0.4$ \\
\hline Epoch & $50,60,70,80,90,100$, \\
& $200,400,600,800,1000$
\end{tabular}

Neuron

$$
10,20,30
$$

\subsection{Backpropagation Neural Network}

\section{Backpropagation Neural Netwok} (BPNN) merupakan sebuah algoritma yang digunakan pada Artificial Nueral Network (ANN) dengan pembelajaran terawasi yang akan menyesuaikan bobot secara berulang yang bertujuan untuk mendapat nilai error terkecil antara target dengan hasil prediksi yang didapat. Backpropagation Neural Network memiliki kemampuan dalam interpolasi non-linear yang dapat menentukan hubungan ataupun fungsi dari dua atau lebih variabel yang memiliki dua maupun lebih variabel non-linear. Metode ini secara luas digunakan dalam aplikasi teknik untuk prediksi dan optimalisasi [7]. BPNN dapat memperkirakan fungsi nonlinear apapun dengan presisi yang berubah-ubah. BPNN terdiri dari 3 layer yaitu hidden layer, input layer dan output layer.

\subsection{Reccurent Neural Netwok Dengan Arsitektur Long Short Term Memory}

\subsubsection{Reccurent Neural Network}

Recurrent Neural Network adalah generalisasi feedforward neural network yang telah memiliki memori internal. Sesuai dengan namanya Recurrent, algoritma ini memiliki sifat pengulangan ataupun rekursif, karena melakukan fungsi yang sama untuk setiap data, sementara output dan input saat ini tergantung pada satu penghitungan fungsi sebelumnya. Setelah menghasilkan output, output kemudian disalin dan dikirim Kembali kedalam fungsi rekursif tersebut. Untuk membuat sebuah keputusan, algoritma ini mempertimbangkan input saat ini dan output yang telah dipelajari dari input sebelumnya.

\subsubsection{Long Short Term Memory}

Long Short-term Memory (LSTM) merupakan jenis arsitektur ataupun pengembangan dari algoritma Recurrent Neural Network $(R N N)$. Dalam pada proses algoritma $R N N$, nilai output yang dihasilkan pada proses terakhir, akan dijadikan sebagai nilai input tahap yang sedang berjalan saat ini. LSTM menjadi sebuah solusi untuk ketergantungan jangka Panjang dari RNN dimana RNN tidak dapat memprediksi data yang tersimpan dalam memory jangka panjang, namun dapat memberikan prediksi yang cukup akurat dari beberapa informasi data terakhir. Karena celah kesenjangan dari RNN tidak memberikan performa yang semakin efisien. LTSM secara baku, dapat menyimpan informasi dalam jangka waktu yang cukup lama, yang dapat digunakan untuk memproses, memprediksi, dan mengklasifikasikan bedasarkan data rangkaian waktu. Karena LSTM sangat efektif dalam mengumpulkan ketergantungan data dalam jangka panjang, tanpa menghadapi rintangan untuk pengoptimalan yang mengganggu pada RNN sederhana, LSTM telah digunakan untuk memajukan berbagai ilmu pengetahuan dalam bidang sains, teknologi, dan juga seni. Beberapa yang termasuk dalam kemajuan tersebut seperti pengenalan dan pembuatan tulisan tangan, pemodelan juga penerjemahan bahasa, dan prediksi yang lebih akurat dengan berdasar pada data rangkaian waktu atau time-series.

\section{HASIL DAN PEMBAHASAN}

Pada bagian ini dijelaskan mengenai hasil dan pembahasan dari implementasi yang telah dilakukan pada penelitian ini. Hasil yang telah diperoleh dari tahap implementasi dan juga pembahasan dari hasil yang didapatkan.

1. Percobaan Prediksi Tinggi Curah Hujan Menggunakan Algoritma BPNN dan RNN Dengan Arsitektur LSTM

Pada bagian ini akan diuraikan hasil dari prediksi tinggi curah hujan berdasarkan data cuaca menggunakan algoritma BPNN dan juga RNN dengan arsitektur LSTM. Percobaan dilakukan untuk setiap parameternya. Hal ini dilakukan untuk mendapatkan hasil yang optimum dan valid. Hasil dari percobaan tersebut menghasilkan nilai RMSE dimana nilai RMSE tersebut adalah nilai error dari hasil prediksi yang dibandingkan dengan data aktualnya. Setelah mendapatkan nilai RMSE dari setiap hasil dari algoritma BPNN dan RNN dengan arsitektur LSTM, maka akan 
dibandingkan hasil dari nilai RMSE yang didapat untuk menentukan pemodelan terbaik dalam melakukan prediksi tinggi curah hujan.

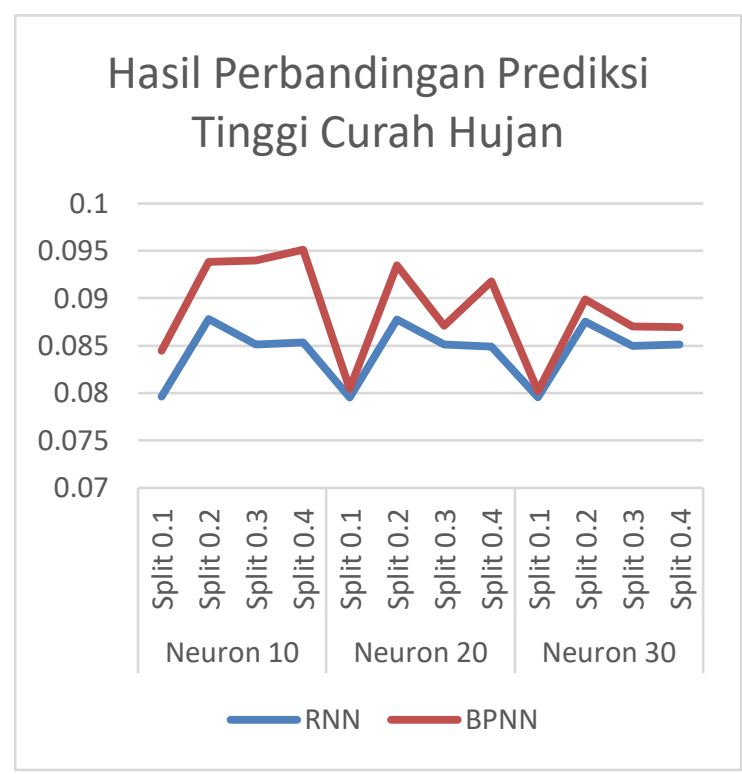

Gambar 2. Grafik Perbandingan RMSE Prediksi Algoritma RNN dan BPNN

Setelah dilakukan proses pemodelan prediksi curah hujan menggunakan Artificial Neural Network (ANN) dengan algoritma BPNN dan RNN dengan metode LSTM. Berdasarkan hasil pemodelan tersebut ditemukan bahwa Backpropagation Neural Network berhasil menjalankan pemodelan prediksi dengan nilai terkecil 0.079535, yang diperoleh dengan melakukan konfigurasi 20 Neuron, 1000 Epoch, dan validation split 0,1 . Hal tersebut terjadi dikarenakan pada pemodelan tersebut digunakan validation split 0.1 yang dimana dataset akan dibagi menjadi $90 \%$ data train dan $10 \%$ data test. Kemudian pada pemodelan tersebut juga digunakan epoch yang paling besar yaitu 1000 yang membuat mesin melakukan train sebanyak 1000 kali terhadap data train.

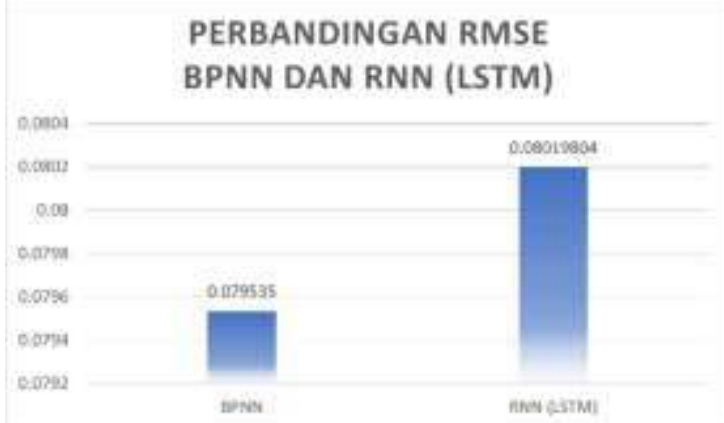

Gambar 3. Perbandingan RMSE terkecil Algoritma RNN dan BPNN
2. Percobaan Prediksi Kecepatan Angin Menggunakan Algoritma BPNN dan RNN Dengan Arsitektur LSTM

Pada bagian ini akan diuraikan hasil dari prediksi kecepatan angin hujan berdasarkan data cuaca menggunakan algoritma BPNN dan juga RNN dengan arsitektur LSTM. Percobaan dilakukan untuk setiap parameternya. Hal ini dilakukan untuk mendapatkan hasil yang optimum dan valid. Hasil dari percobaan tersebut menghasilkan nilai RMSE dimana nilai RMSE tersebut adalah nilai error dari hasil prediksi yang dibandingkan dengan data aktualnya. Setelah mendapatkan nilai RMSE dari setiap hasil dari

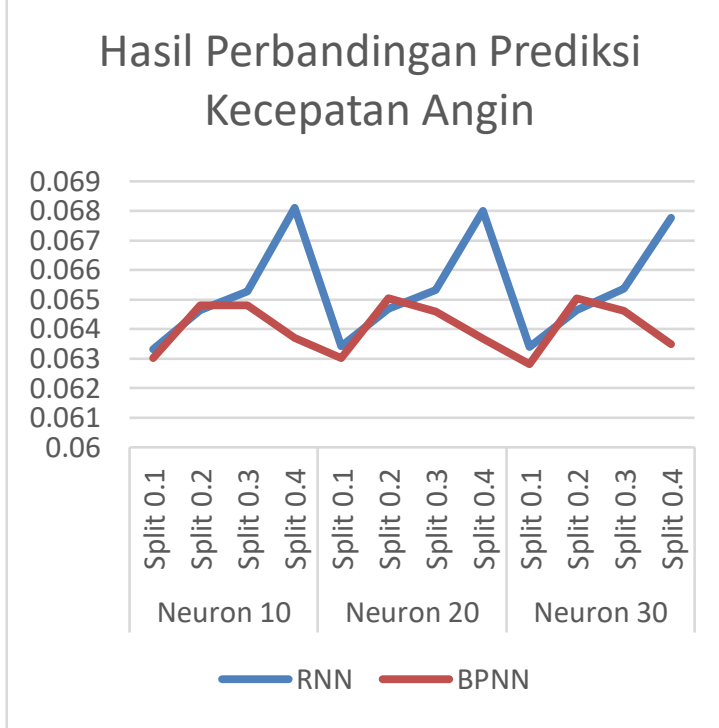

Gambar 4. Grafik Perbandingan RMSE Prediksi

Kecepatan Angin Algoritma RNN dan BPNN

algoritma BPNN dan RNN dengan arsitektur LSTM, maka akan dibandingkan hasil dari nilai RMSE yang didapat untuk menentukan pemodelan terbaik dalam melakukan prediksi kecepatan angin.

Setelah dilakukan proses pemodelan prediksi kecepatan angin menggunakan Artificial Neural Network (ANN) dengan algoritma BPNN dan RNN dengan metode LSTM. Berdasarkan hasil pemodelan tersebut ditemukan bahwa Reccurent Neural Network dengan metode Long Short Term Memory berhasil menjalankan pemodelan prediksi dengan nilai terkecil 0.06281251 , yang diperoleh dengan melakukan konfigurasi 30 Neuron, 800 Epoch, dan validation split 0,1 . Hal tersebut terjadi dikarenakan pada pemodelan tersebut digunakan validation split 0.1 yang dimana dataset akan dibagi menjadi $90 \%$ data train dan $10 \%$ data test. Kemudian pada pemodelan 
tersebut juga digunakan epoch yang paling besar yaitu 800 yang membuat mesin melakukan train sebanyak 800 kali terhadap data train.

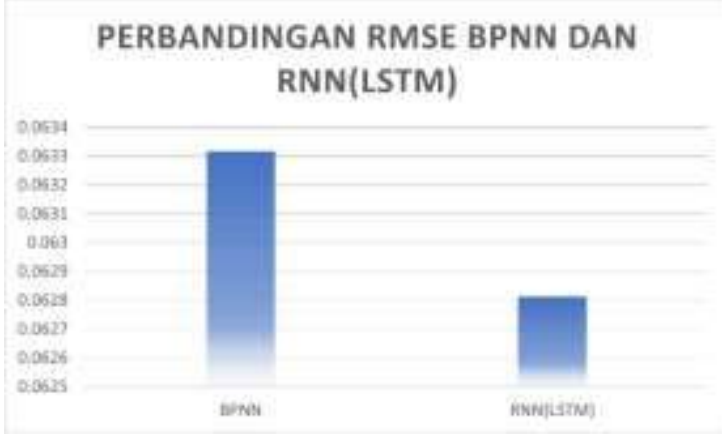

Gambar 2. Perbandingan RMSE Terkecil Prediksi Kecepatan Angin Algoritma RNN dan BPNN

3. Korelasi Antar Variabel-Variabel Yang Mempengaruhi Hasil Pemodelan Prediksi

Berdasarkan nilai pemodelan terbaik pada pemodelan prediksi tinggi curah hujan serta kecepatan angin, maka dilakukan analisis pada variable-variabel yang digunakan. Sebelum melakukan pengurangan variabel, terlebih dahulu dilakukan pendekatan statiska multicollinearity untuk melihat korelasi antara dua atau lebih variabel yang digunakan dalam percobaan ini. Pendekatan multicollinearity yang dilakukan, menggunakan Teknik Variance Inflation Factor (VIF) menunjukkan hasil korelaasi antar variabel sebagai berikut.

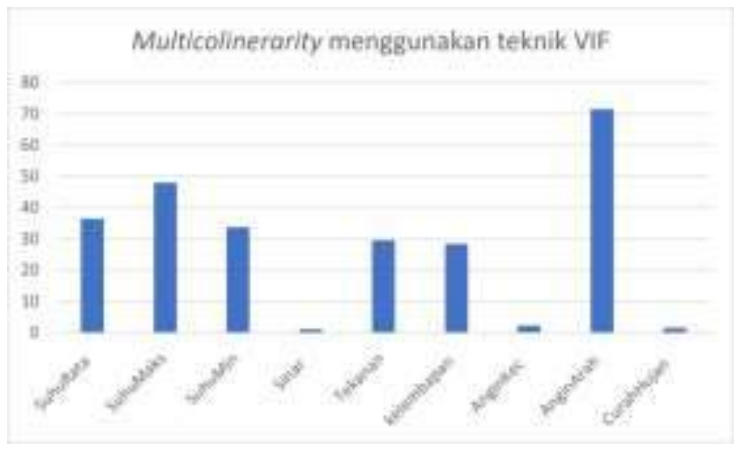

Gambar 3. Grafik Multicolinearity untuk menilai korelasi antar variabel.

Berdasarkan hasil yang diperoleh melalui pendekatan multicollinearity dapat dilihat bahwa terdapat beberapa variabel yang berkorelasi pada data yang digunakan. Suhu, tekanan, dan kelembapan menunjukkan korelasi yang tinggi antar variabel, ini berarti suhu mempengaruhi perubahan tekanan dan kelembapan, tekanan mempengaruhi suhu dan kelempaban, kelembapan mempengaruhi suhu dan tekanan, serta begitu juga sebaliknya. Untuk mengetahui lebih lanjut pengaruh masing-masing variabel tersebut, dilakukan analisis menggunakan pemodelan dengan nilai RMSE terkecil sesuai dengan konfigurasi neuron, epoch, serta validation split yang mendapatkan nilai RMSE terkecil, dengan menghapus variabel satu per satu secara bergantian untuk melihat perolehan nilai RMSE yang dihasilkan. Selisih yang dihasilkan oleh perbedaan nilai RMSE tersebut menunjukkan bahwa setiap variabel bertujuan untuk mendapatkan nilai RMSE terkecil. Semakin besar nilai ataupun selisih yang dihasilkan oleh penghapusan satu variabel dengan penggunan variable menunjukkan peran variabel tersebut dalam mendapatkan nilai RMSE terkecil.

\section{KESIMPULAN}

Berdasarkan hasil yang telah diperoleh selama proses pengerjaan yaitu melakukan prediksi terhadap curah hujan dan kecepatan angin maka dapat disimpulkan bahwa pemodelan terbaik dalam melakukan prediksi curah hujan adalah dengan algoritma Backprpagation Neural Network yaitu dengan dengan nilai RMSE 0.079535 yaitu dengan 20 neuron, 1000 epoch, serta validation split 0.1 . Untuk pemodelan terbaik dalam melakukan prediksi kecepatan angin adalah dengan menggunakan algoritma Reccurent Neural Network dengan menggunakan arsitektur Long Short Term Memory (LSTM) yaitu dengan nilai RMSE yang diperoleh berada pada nilai 0.06281251 dengan 30 neuron, 800 epoch, serta validation split 0.1 .

\section{SARAN}

Berdasarkan hasil analisis dan kesimpulan, saran yang dapat dilakukan ataupun dikembangkan untuk penelitian selanjutnya adalah pada penelitian selanjutnya dapat membangun sistem yang berintegrasi dengan perangkat yang memiliki kemampuan mengukur nilai dari variabel-variabel, seperti OBS (Alat penakar curah hujan biasa), Termokopel (Alat pengukur temperature udara), dan Anemometer (Pengukur Kecepatan Angin) yang umum digunakan dan menyimpan data dengan variable-variable yang digunakan pada suatu server atau penyimpanan database, sehingga data dapat digunakan seperti pada penilitian ini, dengan interval waktu yang dapat 
disesuaikan dengan kebutuhan sehingga data yang diperoleh dapat lebih akurat untuk membangun pemodelan pada suatu wilayah tertentu. Dan juga dapat menambah data cuaca yang digunakan pada penelitian dari stasiun cuaca lainnya seperti data melalui Stasiun Pelabuhan Perikanan Sibolga. Atau bisa juga menggunakan data melalui obsevasi udara atas seperti Radiosonde. Hal ini memungkinkan peningkatkan performa dari model yang digunakan, karena dengan menggunakan data observasi udara atas, maka dapat diketahui bagaimana kondisi atmosfer secara vertikal dan sifat dari atmosfersaat itu apakah stabil atau labil.

\section{UCAPAN TERIMA KASIH}

Penelitian ini dapat terlaksana dengan baik berkat bantuan dari berbagai pihak, untuk itu peneliti mengucapkan terima kasih kepada Ibu Nenni Mona Aruan S.Pd., M.Si, selaku dosen pembimbing serta Bapak Lit Malem Ginting S.Si, MT dan Ibu Ike Fitriyaningsih, S.Si., M.Si.. selaku dosen penguji yang telah memberikan kritik dan saran yang membangun dalam pelaksanaan penelitian ini.

\section{DAFTAR PUSTAKA}

[1] Andhika, N., 2017. Penerapan Algoritma Klasifikasi Data Mining C4.5 Pada Dataset Cuaca Wilayah Bekasi. Konferensi Nasional Ilmu Sosial dan Teknologi (KNiST).

[2] RYAN GALIH PERMANA, E. R. D., 2015. PERANCANGAN DAN PENGUJIAN PENAKAR HUJAN TIPE TIPPING BUCKET DENGAN SENSOR PHOTO INTERRUPTER BEBASIS ARDUINO.

[3] Cryer, B., 2019. HACKERNOON. [Online] Available at: https://hackernoon.com/9reasons-why-you-should-keep-learningmachine-learning-7n7h307n. [Accessed 2111 2020].

[4] Maulana, D. E. R., 2017. Prediksi Intensitas Hujan Kota Surabaya dengan Matlab Menggunakan Random Forest dan CART.

[5] Lumban Raja, B. \& Siagian, K., 2018. Prediksi Curah Hujan dengan BPNN. IT Del journal.

[6] Oktaviani, C. \& Afdal, 2013. Prediksi Curah Hujan Bulanan Menggunakan Jaringan Syaraf Tiruan Dengan Beberapa Fungsi Pelatihan Backpropagation. Jurnal Fisika Unand.
[7] YIN, F., MAO, H., HUA, L., GUO, W., and SHU, M. 2011 "Back Propagation neural network modeling for warpage prediction and optimization of plastic products during injection molding." 